\title{
A MULTI-OBJECTIVE INPUT-OUTPUT MODEL TO ASSESS E4 IMPACTS OF BUILDING RETROFITTING MEASURES TO IMPROVE ENERGY EFFICIENCY
}

\section{Carla OLIVEIRA HENRIQUES ${ }^{\mathrm{a}, \mathrm{d}}$, Dulce Helena COELHO ${ }^{\mathrm{b}, \mathrm{d}}$, Carlos Henggeler ANTUNES ${ }^{c, d}$}

${ }^{a}$ Polytechnic Institute of Coimbra, ISCAC, Quinta Agrícola, Bencanta, 3040-316 Coimbra, Portugal

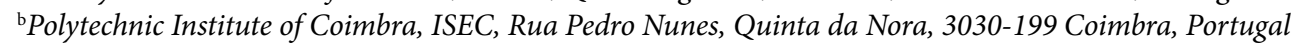
${ }^{c}$ University of Coimbra, DEEC, 3030-290 Coimbra, Portugal 'INESC Coimbra, Rua Antero de Quental, 199, 3030-030 Coimbra, Portugal

Received 22 November 2013; accepted 27 April 2014

\begin{abstract}
This paper develops a bottom-up approach in the scope of a multi-objective linear programming model (MOLP) based on Input-Output (I-O) analysis to account for investment options aimed at improving the thermal properties of building envelope (e.g., the insulation of external walls and roof, and the replacement of window frames and window glazing). This methodological framework aims at assessing the trade-offs between the overall employment, GDP and energy savings associated with the building sector (residential, private services and public services). Distinct impacts, namely on direct and indirect employment generation, environment ( $\mathrm{CO}_{2}$ emissions), energy security supply (energy imports and renewable energy production) and other relevant economic indicators are also analysed. Different sets of input parameters for the economic context and the environmental impacts have been defined as interval coefficients to account for uncertainty. Robust solutions are then obtained by considering the minimisation of the worst possible deviation of the interval objective functions to the corresponding interval ideal solutions.
\end{abstract}

Keywords: energy efficiency retrofitting measures, building stock, MOLP, I-O analysis, interval programming, economy-energy-environment-employment (E4) interactions.

JEL Classification: C67, Q43, C61.

\section{Introduction}

The building sector is responsible for about $40 \%$ and $30 \%$ of total energy consumption in the European Union (EU) and Portugal, respectively. Therefore, this sector offers a significant reduction potential for energy consumption, $\mathrm{CO}_{2}$ emissions and energy dependence

Corresponding author Carla Oliveira Henriques

E-mail: coliv@inescc.pt 
(Directive 2010/31 EU). In this framework, the Energy Efficiency Plan (EEP) (Communication of the European Commission 109/2011) is focused on the instruments aimed at promoting the process of retrofitting in public and private buildings and thus improving the energy performance of their construction components and appliances. In Portugal, the National Energy Strategy for 2020 (NES 2020 - Cabinet Resolution 29/2010) also accounts for the approval of a National Energy Efficiency Action Plan (NEEAP - Cabinet Resolution 20/2013) regarding energy efficiency guidelines. Moreover, the Portuguese NES 2020 aims at reinforcing the industrial cluster of energy efficiency, expecting the generation of 21,000 new jobs by 2020 . The enhancement of overall energy efficiency is currently believed to be the cheapest, fastest and most environmentally friendly way to meet a significant portion of the world's energy needs, reducing the necessity of investing in new energy supply and network infrastructures. Therefore, regardless of the evolution of fuel prices, countries need to be on track of energy efficiency policies more thoroughly in the long-term (Kaygusuz 2012). The strong interest in the promotion of energy efficiency may be ascertained in recent studies with specific focus on energy retrofit actions in the building sector. In this context, Ürge-Vorsatz et al. (2007) indicated that the building stock has the highest share of negative and low-cost greenhouse gas reduction potential among all sectors. Scott et al. 2008 analysed the macroeconomic impacts of increasing energy efficiency in the USA residential and commercial building stock using I-O analysis. Cellura et al. (2013) presented an energy and environmental extended I-O model combined with life cycle assessment (LCA) to assess the energy and environmental benefits arising from the Italian policy of tax deduction for energy retrofit actions in buildings. Rysanek, Choudhary (2013) described a methodology for analysis and optimisation of retrofit decisions using dynamic building energy models, consisting of a combined engineeringeconomic assessment of building energy systems. Markaki et al. (2013) exploited the use of $\mathrm{I}-\mathrm{O}$ analysis for estimating the direct, indirect and induced macroeconomic effects associated with the implementation of selected energy conservation measures, including the promotion of renewable energy technologies. Kuckshinrichs et al. (2010) evaluated the social benefits of the German $\mathrm{CO}_{2}$ refurbishment programme for the years 2005-2007 through the use of an extended I-O model to estimate the effect of the refurbishment works on public revenue via taxes and social security contributions. Besides the indubitable benefits on energy supply security, external dependence and the environment, there is an on-going discussion about the employment impacts of promoting energy efficiency measures, in particular of investing in building renovation. Several authors consider that energy efficiency remains politically popular, thus allowing for potential win-win solutions that create jobs and curb greenhouse gas emissions (Lester 2013; Tuominen et al. 2013). Oliveira et al. (2014) provided an estimate of the significant contribution of energy saving measures in the building sector (residential, private services and public services) in net employment generation in Portugal. However, sustainable development requires a balanced and integrated analysis from three main perspectives: social, economic and environmental (Munasinghe 2009). This is especially true for the construction sector, since the built environment has large impacts on these three dimensions of sustainability (Srdić, Šelih 2011). Therefore, to ensure a balanced assessment of trade-offs and synergies among these dimensions, a holistic approach should be used highlighting the impacts of this type of investments on the economy, the energy system, the environment and the employment. 
The main aim of this paper is to provide an assessment of the impacts of the investment in energy saving retrofitting measures in the building sector (residential, private services and public services) on direct and indirect employment generation, the overall employment and GDP, based on an updated version of a previously developed MOLP I-O model (Oliveira, Antunes 2011, 2012; Oliveira et al. 2013). Estimates for other important impacts are also provided, namely on the environment ( $\mathrm{CO}_{2}$ emissions), energy supply security (net energy imports and renewable energy production) and other relevant economic indicators. The paper is organised as follows: section 1 provides the methodological framework, section 2 provides basic concepts; section 3 presents some illustrative results, and finally the last section draws some conclusions and presents future work developments.

\section{Methodological framework and assumptions}

The estimation of the direct (jobs generated from an expenditure or effort taken in a retrofit project) and indirect (jobs generated in the supply chain of an industry that is directly influenced by an expenditure or effort) employment effects associated with the implementation of energy efficiency retrofit investment in the Portuguese building sector is based on the I-O symmetrical product by product table for total flows used in Oliveira et al. (2013), which is given at 2008 current prices. The analysis is focused on residential, private services and public services buildings, considering two different construction stages: buildings dating back to 1945 and buildings constructed within the period 1946 to 1990. These target buildings were chosen because the first regulation related to energy performance and thermal comfort of buildings in Portugal was endorsed in 1990. Four major categories of construction components were considered to be integrated into a retrofitting project: window frames, window glazing, and roof and wall insulation. The total investment costs associated with the execution of the retrofitting investments considered were firstly disaggregated to account for the economic sectors directly engaged with each retrofitting action. We assume in our analysis that the impact on employment regarding these interventions is expected to take place within the country. Figure 1 shows the assignment (in percentage) of the sectoral distribution of each renovation option herein undertook (considering the expected weight of each renovation investment on the overall level of output of each activity sector directly involved in the corresponding renovation measure). This sectoral distribution was based on several experts' judgments, including researchers and practitioners in the field of energy efficiency (Oliveira et al. 2014; Coelho 2012), and allowed the introduction of a bottom-up approach in a previous version of an MOLP I-O model with interval coefficients (for further details please see Oliveira, Antunes 2011, 2012; Oliveira et al. 2013). In order to obtain these coefficients it was necessary to consider the unit investment costs (at basic prices) that are given in Table 1, which were estimated for 2008 (the base year of our study) based on Asadi et al. (2012), Oliveira et al. (2014) and Coelho (2012). The possible negative impacts of energy efficiency measures on employment associated with the reduction of power generation were obtained by considering that the building heating and cooling systems are provided by electric loads. Although this assumption does not follow to recent building stock specifications (particularly in the residential sector), it is reasonable to consider that 
the building stock built before 1990 mainly uses electricity for space heating and cooling. The avoided $\mathrm{CO}_{2}$ emissions attained with each retrofit investment measure were computed using data from European Commission (2010) (emission factors of generation mix). Finally, the characterisation of the building sector was based on Coelho (2012).

Table 1. Unit costs of each retrofit measure

\begin{tabular}{|c|c|c|c|c|c|c|c|c|c|c|}
\hline \multirow{2}{*}{\multicolumn{2}{|c|}{$\begin{array}{l}\text { Retrofit measure cost } \\
\qquad\left(€ / \mathrm{m}^{2}\right)\end{array}$}} & \multicolumn{5}{|c|}{ Year of construction } & & & & \\
\hline & & & $<1945$ & & \multicolumn{2}{|c|}{$1946-1990$} & & & & \\
\hline \multicolumn{2}{|c|}{ Roof thermal insulation } & & 18 & & \multicolumn{2}{|l|}{13} & & & & \\
\hline \multicolumn{3}{|l|}{ Opaque facades } & 35 & 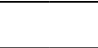 & \multicolumn{2}{|l|}{25} & & & & \\
\hline \multicolumn{3}{|c|}{ Double glazed Windows } & 75 & & \multicolumn{2}{|l|}{75} & & & & \\
\hline \multicolumn{3}{|l|}{ Windows Frame } & 151 & & \multicolumn{2}{|l|}{151} & & & & \\
\hline Windows + Frames & $\begin{array}{l}0.040 \% \\
0.035 \% \\
0.030 \% \\
0.025 \% \\
0.020 \% \\
0.015 \% \\
0.010 \% \\
0.005 \% \\
0.000 \%\end{array}$ & $\begin{array}{c}\mathrm{SD}<45 \\
(4 \mathrm{fc})\end{array}$ & $\begin{array}{l}= \\
\mathrm{SD}<45 \\
(2 \mathrm{fc}) \\
\text { Resid }\end{array}$ & $\begin{array}{l}\left|\begin{array}{l}\mathrm{AB} 46-90 \\
(3 \mathrm{fl}, 4 \mathrm{fc})\end{array}\right| \\
\text { ential }\end{array}$ & $\left|\begin{array}{|c|}\mathrm{AB} 46-90 \\
(3 \mathrm{fl}, 2 \mathrm{fc})\end{array}\right|$ & $\begin{array}{l}-1 \\
\mathrm{AB}<45 \\
(3 \mathrm{fl}) \\
\text { Private }\end{array}$ & $\left|\begin{array}{c}\mathrm{AB} 46-90 \\
(3 \mathrm{fl}) \\
\text { Services }\end{array}\right|$ & $\begin{array}{c}\mid \begin{array}{c}\mathrm{AB}<45 \\
(3 \mathrm{fl}) \\
\text { Public } \mathrm{S}\end{array} \\
\end{array}$ & 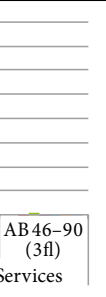 & \multirow{4}{*}{$\begin{array}{l}\text { Chemical products } \\
\text { Basic Metals } \\
\text { Construction } \\
\text { Retail Trade } \\
\text { Products from } \\
\text { non-metallic } \\
\text { minerals } \\
\text { Metallic Products } \\
\text { Gross Trade }\end{array}$} \\
\hline Windows & $\begin{array}{c}0.022 \% \\
0.017 \% \\
0.012 \% \\
0.007 \% \\
0.002 \% \\
-0.003 \%\end{array}$ & $\begin{array}{l}\mathrm{SD}<45 \\
(4 \mathrm{fc})\end{array}$ & $\begin{array}{c}\mathrm{SD}<45 \\
(2 \mathrm{fc}) \\
\text { Resid }\end{array}$ & $\left|\begin{array}{c}\mathrm{AB} 46-90 \\
(3 \mathrm{fl}, 4 \mathrm{fc})\end{array}\right|$ & $\left|\begin{array}{c}\mathrm{AB} 46-90 \\
(3 \mathrm{fl}, 2 \mathrm{fc})\end{array}\right|$ & $\begin{array}{l}\mathrm{AB}<45 \\
(3 \mathrm{fl}) \\
\text { Private }\end{array}$ & $\left|\begin{array}{c}\mathrm{AB} 46-90 \\
(3 \mathrm{fl}) \\
\text { Services }\end{array}\right|$ & $\begin{array}{l}\overline{A B}<45 \\
(3 \mathrm{fl}) \\
\text { Public }\end{array}$ & $\left|\begin{array}{c}\mathrm{AB} 46-90 \\
(3 \mathrm{fl}) \\
\text { Services }\end{array}\right|$ & \\
\hline Facades & $\begin{array}{l}0.035 \% \\
0.030 \% \\
0.025 \% \\
0.020 \% \\
0.015 \% \\
0.010 \% \\
0.005 \% \\
0.000 \%\end{array}$ & $\begin{array}{c}\mathrm{SD}<45 \\
(4 \mathrm{fc})\end{array}$ & $\begin{array}{c}\mid \begin{array}{c}\mathrm{SD}<45 \\
(2 \mathrm{fc})\end{array} \\
\text { Reside }\end{array}$ & $\begin{array}{l}\left|\begin{array}{c}\mathrm{AB} 46-90 \\
(3 \mathrm{fl}, 4 \mathrm{fc})\end{array}\right| \\
\text { ential }\end{array}$ & $\mid \begin{array}{c}\mathrm{AB} 46-90 \\
(3 \mathrm{fl}, 2 \mathrm{fc})\end{array}$ & $\begin{array}{l}\mathrm{AB}<45 \\
(3 \mathrm{fl}) \\
\text { Private } \mathrm{S}\end{array}$ & $\mid \begin{array}{c}\text { AB 46-90 } \\
(3 \mathrm{fl}) \\
\text { Services }\end{array}$ & $\begin{array}{c}\mathrm{AB}<45 \\
(3 \mathrm{fl}) \\
\text { Public } \mathrm{S}\end{array}$ & \begin{tabular}{|c|} 
AB $46-90$ \\
$(3 \mathrm{fl})$ \\
Services
\end{tabular} \mid & \\
\hline Roof & $\begin{array}{l}0.014 \% \\
0.012 \% \\
0.010 \% \\
0.008 \% \\
0.006 \% \\
0.004 \% \\
0.002 \% \\
0.000 \%\end{array}$ & $\begin{array}{c}\mathrm{SD}<45 \\
(4 \mathrm{fc})\end{array}$ & \begin{tabular}{|}
$\mathrm{SD}<45$ \\
$(2 \mathrm{fc})$ \\
$\quad$ Reside
\end{tabular} & $\mid$ & $\left|\begin{array}{c}\mathrm{AB} 46-90 \\
(3 \mathrm{fl}, 2 \mathrm{fc})\end{array}\right|$ & $\begin{array}{c}\mathrm{AB}<45 \\
(3 \mathrm{fl}) \\
\text { Private } \mathrm{S}\end{array}$ & $\left|\begin{array}{c}\mathrm{AB} 46-90 \\
(3 \mathrm{fl}) \\
\text { Services }\end{array}\right|$ & $\begin{array}{l}\mathrm{AB}<45 \\
(3 \mathrm{fl}) \\
\text { Public } \mathrm{S}\end{array}$ & $\left|\begin{array}{c}\overline{\mathrm{AB}} 4 \overline{6-90} \\
(3 \mathrm{fl}) \\
\text { Services }\end{array}\right|$ & \\
\hline
\end{tabular}

Note: $\mathrm{SD}=$ Single Dwelling; $\mathrm{AB}=$ Apartment Building; $\mathrm{fc}=$ facade; $\mathrm{fl}=$ floor; $<45$ - built before 1945 ; 46-90 - built between 1946 and 1990.

Fig. 1. Retrofit investment allocation to activity sectors 


\subsection{The MOLP I-O model}

The MOLP I-O model herein considered has been proposed and used elsewhere (Oliveira, Antunes 2011, 2012; Oliveira et al. 2013). However, some relevant changes are now included: - the introduction of a bottom-up approach that allows incorporating the several retrofit investment options according to different types of buildings (see Fig. 2); - the use of employment multipliers to obtain the impacts of distinct retrofit investments on the overall employment; - the consideration of the potential energy savings and avoided $\mathrm{CO}_{2}$ emissions that may be attained with the implementation of these retrofit measures; - the consideration of different objective functions more consistent with the aim of this study (the maximisation of GDP at constant prices as a proxy for economic growth, the maximisation of the overall employment in the economy, and the maximisation of building retrofitting investments). The model includes two main types of constraints: coherence constraints (derived from the I-O framework) and defining constraints. The economic and environmental defining constraints with interval coefficients have been imposed with interval (upper/lower) bounds consistent with the available data (Oliveira et al. 2013). Upper bounds have also been imposed on the distinct retrofit investment options according to the total amount of retrofit investments foreseen by the new NEEAP (Cabinet Resolution 20/2013) and Martins et al. (2009). Finally, an upper bound on the overall employment has been considered in order to better explore the trade-offs between the different objective functions, and the upper bounds on the renewable energy production have also been reduced according to the new targets endorsed in the new NEEAP.

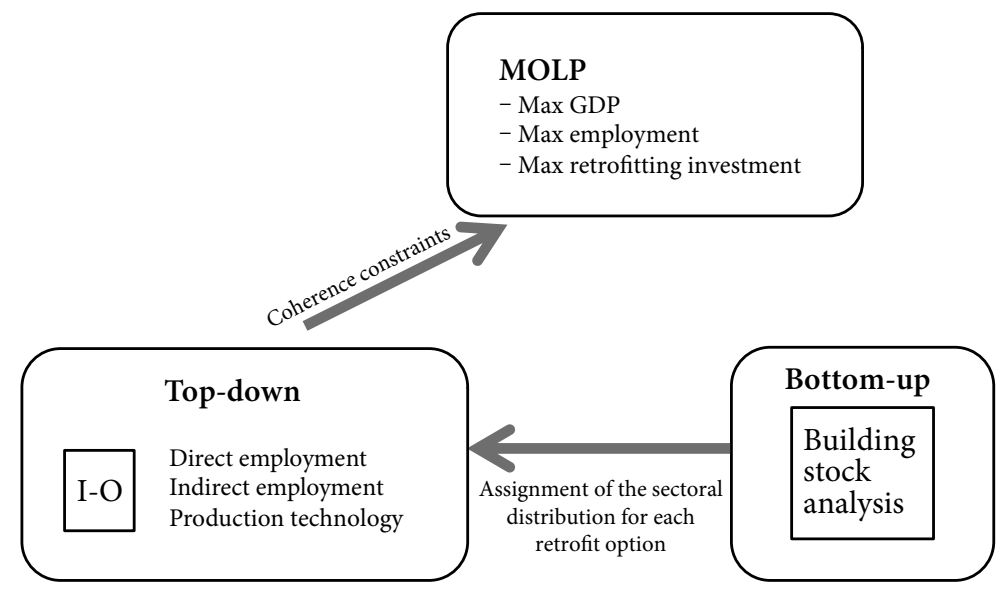

Fig. 2. New structure of the MOLP I-O model

\subsection{I-O employment multipliers}

The overall significance and contribution of an industry to total employment can be calculated by assuming that the sectoral employment ratios are fixed. The indirect contribution of an industry to the total employment (employment multiplier) may be interpreted as the 
impact on the overall employment if the final demand in sector $\mathrm{j}$ increases by one unit. The employment multiplier for sector $j, E_{j}^{m}$, is given by (Oliveira et al. 2014):

$$
E_{j}^{m}=\sum_{i=1}^{n} e_{i} b_{i j},
$$

where $e_{i}$ denotes the number of persons with full time employment (FTE) per one Euro output for sector $i, b_{i j}$ is the $(i j)^{\text {th }}$ element of the closed Leontief inverse matrix and $n$ is the number of sectors. These multipliers represent the total employment for every new employee to meet a unit increase of final demand in sector $j$. However, if we wish to account for the total employment effect resulting from an initial change in employment of sector $j$, the employment multiplier, $E_{j}$, becomes (Oliveira et al. 2014):

$$
E_{j}=\sum_{i=1}^{n} \frac{\left(e_{i}\right) b_{i j}}{e_{j}} .
$$

\section{Illustrative results}

The interactive approach used to obtain compromise solutions to the MOLP I-O model with interval coefficients is based on Oliveira, Antunes (2009). The method starts by computing the interval ideal solutions by considering both the extreme (most pessimistic and most optimistic coefficients) versions of the objective functions and the feasible region (see Table 2). Table 2 contains all individual optimal values for each objective function in a best or worst case scenario, where GDP is given in $10^{6}$ Euro, the level of Employment (EMP) is given in $10^{3}$ persons and the total Retrofit investment is given in $10^{6}$ Euro. The main diagonal of this table corresponds to the ideal solution in the best and worst case scenarios considered. Solutions displayed in Table 2 highlight the following considerations:

1) High level of employment is obtained with high level of GDP, and the conflict between GDP and employment becomes less evident if in the optimisation of GDP the worst case scenario (Solution 2) is considered in which the service sectors have lower output levels, indicating that the activity sectors with higher impact on GDP are not necessarily those with the highest employment generation potential (at least in the best case scenario).

2) The optimisation of GDP and employment does not allow obtaining the highest values for retrofit investments. In fact, in the worst optimal value attained for the retrofit investments (Solution 6) the lowest GDP and overall level of employment are reached.

3) The optimal value obtained for retrofit investment (either in a best or worst case scenario) reaches the upper bound considered (50\% of the total retrofit investment foreseen until 2020). Note that by changing these upper bounds we can exploit the trade-offs with the other objective functions.

4) Although higher impacts on direct employment (DE) and indirect employment (IE) generation are expected to occur in both solutions 5 and 6 (optimisation of retrofit investments either in a best and worst case scenario) the highest overall level of employment is far from its highest value, which although being unrealistic highlights some potential trade-offs between the overall employment and retrofit investment (see Fig. 3). However, in the best case scenario the optimisation of retrofit investment allows obtaining higher overall levels of employment also with high levels for GDP. 
5) The optimal value to GDP (in a worst case scenario) and to employment (either in a best case or worst case scenario) allows reaching an unrealistic increase of the output of agriculture (the purpose of the new upper bound imposed on employment was to grasp the trade-offs between the objective functions). On the other hand, the optimal value to GDP in a best case scenario allows reaching an unrealistic increase of the output of the refining and transportation sector (since this type of models has the problem of specialisation if no upper bounds are considered for the level of output of the activity sectors). This fact leads to the highest $\mathrm{CO}_{2}$ emissions regarding these solutions (see Fig. 4) and highlights the potential trade-offs between GDP and $\mathrm{CO}_{2}$ emissions.

6) Although the expected energy saving potentials and the corresponding avoided $\mathrm{CO}_{2}$ emissions achieve the highest values in solutions 5 and 6 (see the upper graphs of Fig. 4), the overall level of primary energy imports remains with high values that are only exceeded by solution 1 (see the lower graphs of Fig. 4). This fact highlights the trade-off between the energy savings obtained with the overall level of energy imports necessary to sustain the retrofitting measures. However, this trade-off is expected to be diluted in the long run and it is mainly the result of the necessary increase of the output of the activity sectors directly involved in the retrofitting activities, which have high energy intensity: chemical, other non-metallic mineral products, basic metals, fabricated metal products and construction.

The number of buildings subject to the refurbishment options considered in each solution is given in Figure 5 highlighting the impacts of each measure on energy savings (upper part of Fig. 4).

Table 2. Extended payoff table

\begin{tabular}{lcccccc}
\hline & \multicolumn{2}{c}{ Max GDP } & \multicolumn{2}{c}{ Max employment } & \multicolumn{2}{c}{ Max retrofit } \\
\cline { 2 - 7 } & Solution 1 & Solution 2 & Solution 3 & Solution 4 & Solution 5 & Solution 6 \\
\hline GDP Best & $\mathbf{1 9 1 7 7 1}$ & 176137 & 190558 & 174524 & 190550 & 163118 \\
\hline GDP Worst & 180414 & $\mathbf{1 6 7 2 6 4}$ & 180196 & 164923 & 180001 & 154860 \\
\hline EMP Best & 5428 & 7924 & $\mathbf{8 0 0 0}$ & 8000 & 5572 & 5154 \\
\hline EMP Worst & 5428 & 7924 & 8000 & $\mathbf{8 0 0 0}$ & 5572 & 5154 \\
\hline Retrofit Best & 21 & 21 & 22 & 20 & $\mathbf{7 2}$ & 72 \\
\hline Retrofit Worst & 21 & 21 & 22 & 20 & 72 & $\mathbf{7 2}$ \\
\hline
\end{tabular}

Employment Generation from retrofit investments (number of persons)

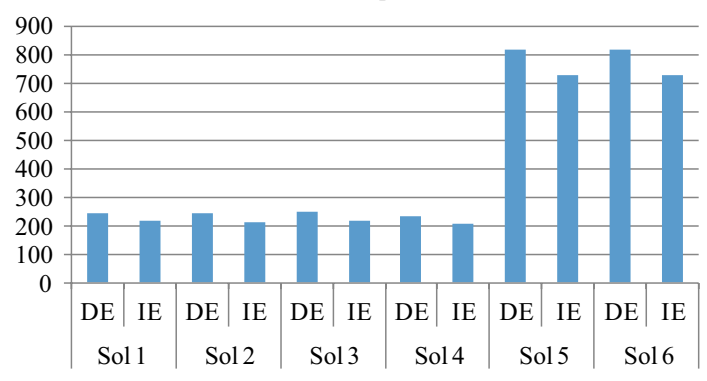

Fig. 3. DE and IE employment from retrofit investments 


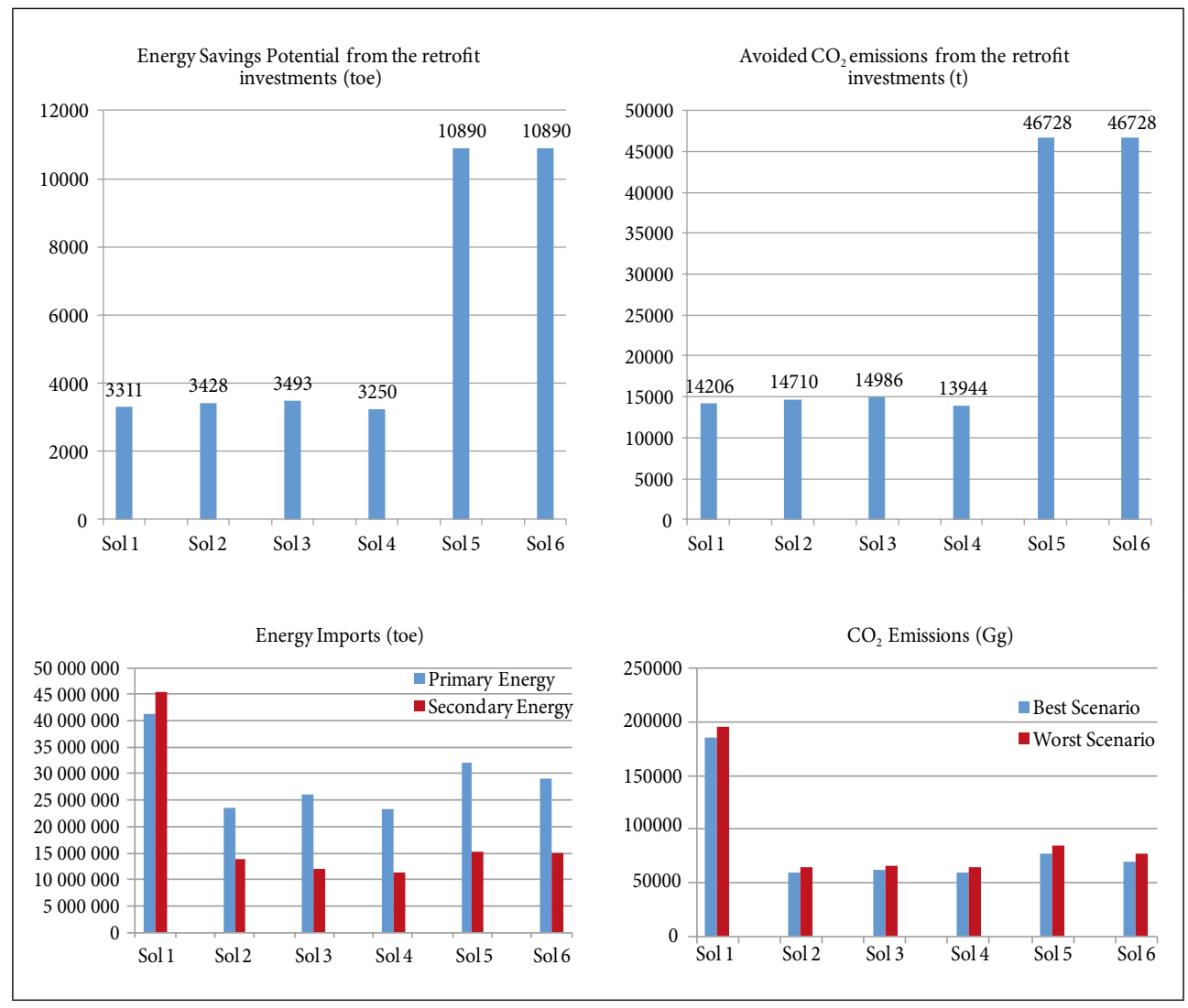

Fig. 4. Expected energy and environmental impacts

Two surrogate deterministic problems may be then formulated by considering the minimisation of the worst possible deviation of the interval objective functions to their corresponding interval ideal solutions as well as both the satisfying (threshold) levels on the constraints and (either more stringent or relaxed) reservation levels on the objective functions values. The choice of the surrogate problem used to obtain new solutions depends on the optimistic or pessimist stances of the Decision-Maker (DM). For illustrative purposes we have considered that the DM has a pessimistic point of view and considers two different sets of coefficients, an intermediate one and an optimistic one (see Fig. 6). A new constraint was added to the overall Employment level (an upper bound consistent with the levels attained for the base year of this study). The level of GDP with an intermediate scenario (threshold level of 0.5) allows obtaining higher values for GDP, but lower values for retrofitting investment (highlighting once more the trade-off between these two axes of evaluation). In both solutions the overall employment level reaches the new upper bound imposed. It can also be seen that with a tighter version of the feasible region (solution 8) the structure of refurbishment investments is changed (see Fig. 6). 


\begin{tabular}{|c|c|c|c|c|c|}
\hline & & \multicolumn{4}{|c|}{$\mathrm{N}^{\circ}$ of Buildings } \\
\hline & Solution 1 & Windows + Frames & Windows & Facades & Roofs \\
\hline \multirow{4}{*}{ Residential } & $\mathrm{SD}<45(4 \mathrm{fc})$ & 205 & 203 & 64 & 93 \\
\hline & $\mathrm{SD}<45(2 \mathrm{fc})$ & 353 & 350 & 110 & 93 \\
\hline & AB $46-90(3 \mathrm{fl}, 4 \mathrm{fc})$ & 427 & 423 & 170 & 257 \\
\hline & AB $46-90(3 \mathrm{fl}, 2 \mathrm{fc})$ & 723 & 716 & 259 & 257 \\
\hline \multirow{2}{*}{ Private services } & $\mathrm{AB}<45(3 \mathrm{fl})$ & 14 & 14 & 26 & 74 \\
\hline & $\mathrm{AB} 46-90(4 \mathrm{fl})$ & 9 & 9 & 22 & 34 \\
\hline \multirow{2}{*}{ Public services } & $\mathrm{AB}<45(3 \mathrm{fl})$ & 0 & 0 & 1 & 1 \\
\hline & $\mathrm{AB} 46-90(3 \mathrm{fl})$ & 0 & 0 & 1 & 1 \\
\hline \multirow{2}{*}{\multicolumn{2}{|c|}{ Total }} & 1.732 & 1.716 & 651 & 811 \\
\hline & & \multicolumn{4}{|c|}{ No of Buildings } \\
\hline & Solution 2 & Windows + Frames & Windows & Facades & Roofs \\
\hline \multirow{4}{*}{ Residential } & $\mathrm{SD}<45(4 \mathrm{fc})$ & 228 & 220 & 55 & 82 \\
\hline & $\mathrm{SD}<45(2 \mathrm{fc})$ & 393 & 378 & 95 & 82 \\
\hline & $\mathrm{AB} 46-90(3 \mathrm{fl}, 4 \mathrm{fc})$ & 475 & 458 & 146 & 227 \\
\hline & AB $46-90(3 \mathrm{fl}, 2 \mathrm{fc})$ & 805 & 775 & 223 & 227 \\
\hline \multirow{2}{*}{ Private services } & $\mathrm{AB}<45(3 \mathrm{fl})$ & 16 & 15 & 22 & 65 \\
\hline & AB 46-90 (4fl) & 10 & 10 & 19 & 30 \\
\hline \multirow{2}{*}{ Public services } & $\mathrm{AB}<45(3 \mathrm{fl})$ & 0 & 0 & 1 & 1 \\
\hline & AB 46-90 (3fl) & 0 & 0 & 1 & 1 \\
\hline \multirow{2}{*}{\multicolumn{2}{|c|}{ Total }} & 1.927 & 1.857 & 561 & 714 \\
\hline & & \multicolumn{4}{|c|}{$\mathrm{N}^{\circ}$ of Buildings } \\
\hline & Solution 3 & Windows + Frames & Windows & Facades & Roofs \\
\hline \multirow{4}{*}{ Residential } & $\mathrm{SD}<45(4 \mathrm{fc})$ & 236 & 218 & 57 & 84 \\
\hline & $\mathrm{SD}<45(2 \mathrm{fc})$ & 406 & 375 & 97 & 84 \\
\hline & AB $46-90(3 \mathrm{fl}, 4 \mathrm{fc})$ & 492 & 454 & 150 & 232 \\
\hline & AB $46-90(3 \mathrm{fl}, 2 \mathrm{fc})$ & 833 & 769 & 229 & 232 \\
\hline \multirow{2}{*}{ Private services } & $\mathrm{AB}<45(3 \mathrm{fl})$ & 17 & 15 & 23 & 66 \\
\hline & AB 46-90 (4fl) & 10 & 10 & 19 & 31 \\
\hline \multirow{2}{*}{ Public services } & $\mathrm{AB}<45(3 \mathrm{fl})$ & 0 & 0 & 1 & 1 \\
\hline & AB 46-90 (3fl) & 0 & 0 & 1 & 1 \\
\hline \multirow{2}{*}{\multicolumn{2}{|c|}{ Total }} & 1.995 & 1.843 & 577 & 732 \\
\hline & & \multicolumn{4}{|c|}{$\mathrm{N}^{\circ}$ of Buildings } \\
\hline & Solution 4 & Windows + Frames & Windows & Facades & Roofs \\
\hline \multirow{4}{*}{ Residential } & $\mathrm{SD}<45(4 \mathrm{fc})$ & 214 & 206 & 54 & 80 \\
\hline & $\mathrm{SD}<45(2 \mathrm{fc})$ & 369 & 354 & 93 & 80 \\
\hline & AB $46-90(3 \mathrm{fl}, 4 \mathrm{fc})$ & 446 & 428 & 144 & 222 \\
\hline & AB $46-90(3 \mathrm{fl}, 2 \mathrm{fc})$ & 756 & 726 & 219 & 222 \\
\hline \multirow{2}{*}{ Private services } & $\mathrm{AB}<45(3 \mathrm{fl})$ & 15 & 14 & 22 & 63 \\
\hline & AB $46-90(4 \mathrm{fl})$ & 9 & 9 & 18 & 30 \\
\hline \multirow{2}{*}{ Public services } & $\mathrm{AB}<45(3 \mathrm{fl})$ & 0 & 0 & 1 & 1 \\
\hline & $\mathrm{AB} 46-90(3 \mathrm{fl})$ & 0 & 0 & 1 & 1 \\
\hline & Total & 1.810 & 1.739 & 551 & 699 \\
\hline & & & $\mathrm{N}^{\circ}$ of $\mathrm{Br}$ & & \\
\hline & Solutions 5 and 6 & Windows + Frames & Windows & Facades & Roofs \\
\hline & $\mathrm{SD}<45(4 \mathrm{fc})$ & 619 & 619 & 227 & 418 \\
\hline Residential & $\mathrm{SD}<45(2 \mathrm{fc})$ & 1.065 & 1.065 & 391 & 418 \\
\hline Residential & AB $46-90(3 \mathrm{fl}, 4 \mathrm{fc})$ & 1.289 & 1.289 & 605 & 1.158 \\
\hline & AB $46-90(3 f l, 2 f c)$ & 2.183 & 2.183 & 922 & 1.158 \\
\hline & $\mathrm{AB}<45(3 \mathrm{fl})$ & 44 & 44 & 92 & 331 \\
\hline Private services & AB 46-90 (4fl) & 27 & 27 & 77 & 155 \\
\hline & $\mathrm{AB}<45(3 \mathrm{fl})$ & 1 & 1 & 2 & 3 \\
\hline Public services & AB 46-90 (3fl) & 1 & 1 & 2 & 3 \\
\hline & Total & 5.230 & 5.230 & 2.319 & 3.645 \\
\hline
\end{tabular}

Fig. 5. Number of buildings subject to refurbishment interventions for the first six solutions 


\begin{tabular}{|c|c|c|c|c|c|}
\hline & \multicolumn{5}{|c|}{$\mathrm{N}^{\circ}$ of Buildings } \\
\hline & Solution 7 & Windows + Frames & Windows & Facades & Roofs \\
\hline \multirow{4}{*}{ Residential } & $\mathrm{SD}<45(4 \mathrm{fc})$ & 226 & 203 & 361 & 734 \\
\hline & $\mathrm{SD}<45(2 \mathrm{fc})$ & 388 & 349 & 621 & 734 \\
\hline & AB $46-90(3 \mathrm{fl}, 4 \mathrm{fc})$ & 470 & 423 & 960 & 2.031 \\
\hline & $\mathrm{AB} 46-90(3 \mathrm{fl}, 2 \mathrm{fc})$ & 796 & 716 & 1.464 & 2.031 \\
\hline \multirow{2}{*}{ Private services } & $\mathrm{AB}<45(3 \mathrm{fl})$ & 16 & 14 & 146 & 580 \\
\hline & AB 46-90 (4fl) & 10 & 9 & 123 & 272 \\
\hline \multirow{2}{*}{ Public services } & $\mathrm{AB}<45(3 \mathrm{fl})$ & 0 & 0 & 4 & 6 \\
\hline & AB 46-90 (3fl) & 0 & 0 & 4 & 6 \\
\hline \multirow{2}{*}{\multicolumn{2}{|c|}{ Total }} & \multirow[t]{2}{*}{1.906} & 1.716 & \multirow{2}{*}{$\begin{array}{l}3.684 \\
\text { gs }\end{array}$} & \multirow[t]{2}{*}{6.394} \\
\hline & & & No of Buildings & & \\
\hline & Solution 8 & Windows + Frames & Windows & Facades & Roofs \\
\hline \multirow{4}{*}{ Residential } & $\mathrm{SD}<45(4 \mathrm{fc})$ & 309 & 371 & 162 & 264 \\
\hline & $\mathrm{SD}<45(2 \mathrm{fc})$ & 531 & 638 & 279 & 264 \\
\hline & AB 46-90 (3fl, 4 fc) & 642 & 772 & 431 & 732 \\
\hline & AB $46-90(3 \mathrm{fl}, 2 \mathrm{fc})$ & 1.088 & 1.307 & 657 & 732 \\
\hline \multirow{2}{*}{ Private services } & $\mathrm{AB}<45(3 \mathrm{fl})$ & 22 & 26 & 65 & 209 \\
\hline & AB 46-90 (4fl) & 14 & 16 & 55 & 98 \\
\hline \multirow{2}{*}{ Public services } & $\mathrm{AB}<45(3 \mathrm{fl})$ & 1 & 1 & 2 & 2 \\
\hline & AB 46-90 (3fl) & 1 & 1 & 2 & 2 \\
\hline & Total & 2.605 & 3.132 & 1.654 & 2.303 \\
\hline & & \multicolumn{4}{|c|}{ No of Buildings } \\
\hline & Solution 9 & Windows + Frames & Windows & Facades & Roofs \\
\hline \multirow{4}{*}{ Residential } & $\mathrm{SD}<45(4 \mathrm{fc})$ & 619 & 619 & 227 & 418 \\
\hline & $\mathrm{SD}<45(2 \mathrm{fc})$ & 1.065 & 1.065 & 391 & 418 \\
\hline & AB $46-90(3 \mathrm{fl}, 4 \mathrm{fc})$ & 1.289 & 1.289 & 605 & 1.158 \\
\hline & $\mathrm{AB} 46-90(3 \mathrm{fl}, 2 \mathrm{fc})$ & 2.183 & 2.183 & 922 & 1.158 \\
\hline \multirow{2}{*}{ Private services } & $\mathrm{AB}<45(3 \mathrm{fl})$ & 44 & 44 & 92 & 331 \\
\hline & AB 46-90 (4fl) & 27 & 27 & 77 & 155 \\
\hline \multirow{2}{*}{ Public services } & $\mathrm{AB}<45(3 \mathrm{fl})$ & 1 & 1 & 2 & 3 \\
\hline & AB 46-90 (3fl) & 1 & 1 & 2 & 3 \\
\hline \multicolumn{2}{|r|}{ Total } & 5.230 & 5.230 & 2.319 & 3.645 \\
\hline
\end{tabular}

Fig. 6. Number of buildings subject to refurbishment interventions for the solutions obtained with a pessimistic stance

\section{Conclusions}

Reconciling the economic, social and environmental aspects within a holistic and balanced sustainable development framework is of utmost importance for practical policy making. This study encompasses these evaluation dimensions and reports some illustrative results on the analysis of the main impacts due to the implementation of four specific energy efficiency measures in building retrofitting (roof and facade insulation, and window glazing with or without frame replacement) on direct and indirect job creation, overall employment and GDP. A holistic methodology was proposed by introducing a bottom-up approach in an MOLP I-O model that allows the assessment of avoided energy consumption and $\mathrm{CO}_{2}$ emissions associated with the retrofitting measures. This methodological framework also allows performing the analysis of the required energy imports that feed the activity sectors directly engaged with those measures. It can be concluded that the positive impact of the measures herein considered on energy consumption and $\mathrm{CO}_{2}$ emissions is not straightforward, since the activity sectors directly involved in each retrofitting intervention have high energy in- 
tensity. Although the highest direct and indirect job generation potential can be obtained in the solutions that optimise renovation investments, a trade-off is found with the generation of overall employment, in particular when the worst case scenario is considered, regarding the economic projections incorporated in the model coefficients and parameters. If the best case scenario is considered, the optimisation of retrofitting investment allows reaching high, albeit realistic, values both for GDP and the employment level.

\section{Acknowledgements}

This work has been framed under the Energy for Sustainability Initiative of the University of Coimbra and supported by Energy and Mobility for Sustainable Regions Project CENTRO07-0224-FEDER-002004 and FCT under project grant.

\section{References}

Asadi, E.; Silva, M. G.; Antunes, C. H.; Dias, L. 2012. A multi-objective optimization model for building retrofit strategies using TRNSYS simulations, GenOpt and MATLAB, Building and Environment 56: 370-378. http://dx.doi.org/10.1016/j.buildenv.2012.04.005

Cabinet Resolution 20/2013 [online], [cited 06 January 2014]. Available from Internet: https://dre.pt/ pdf1sdip/2013/04/07000/0202202091.pdf

Cabinet Resolution 29/2010 [online], [cited 06 January 2014]. Available from Internet: http://dre.pt/ pdf1sdip/2010/04/07300/0128901296.pdf

Cellura, M.; Di Gangi, A.; Longo, S.; Orioli, A. 2013. An Italian input-output model for the assessment of energy and environmental benefits arising from retrofit actions of buildings, Energy and Buildings 62: 97-106. http://dx.doi.org/10.1016/j.enbuild.2013.02.056

Coelho, D. H. 2012. Decision support in integrated urban energy planning: PhD thesis. University of Coimbra (in Portuguese).

Communication of the European Commission 109/2011 [online], [cited 06 January 2014]. Available from Internet: http://eur-lex.europa.eu/LexUriServ/LexUriServ.do?uri=COM:2011:0109:FIN:EN:PDF

Directive 2010/31 EU [online], [cited 06 January 2014]. Available from Internet: http://eur-lex.europa. eu/LexUriServ/LexUriServ.do?uri= OJ:L:2010:153:0013:0035:EN:PDF

Kaygusuz, K. 2012. Energy for sustainable development: a case of developing countries, Renewable and Sustainable Energy Reviews 16(2): 1116-1126. http://dx.doi.org/10.1016/j.rser.2011.11.013

Kuckshinrichs, W.; Kronenberg, T.; Hansen, P. 2010. The social return on investment in the energy efficiency of buildings in Germany, Energy Policy 38(8): 4317-4329.

http://dx.doi.org/10.1016/j.enpol.2010.03.060

Lester, T. 2013. Dedicating new real estate transfer taxes for energy efficiency: a revenue option for scaling up Green Retrofit Programs, Energy Policy 62: 809-820.

http://dx.doi.org/10.1016/j.enpol.2013.07.050

Markaki, M.; Belegri-Roboli, A.; Michaelides, P.; Mirasgedis, S.; Lalas, D. P. 2013. The impact of clean energy investments on the Greek economy: an input-output analysis (2010-2020), Energy Policy 57: 263-275. http://dx.doi.org/10.1016/j.enpol.2013.01.047

Martins, B.; Vital, C.; Adão, D.; Neves, F.; Martins, L.; Ramalho, M.; Afonso, F. 2009. The rehabilitation market. Framework, Relevance and Perspectives (in Portuguese) [online], [cited 28 September 2013]. Available from Internet: http://prewww.aecops.pt/pls/daecops3/WEB_EXTRACT_EXTERNAL.GET_EXTERNAL?code $=29390781 \&$ col_ext=FILE1\&tab=blist_downloads 
Munasinghe, M. 2009. Macroeconomics and sustainable development: applying the sustainomics framework, in J. M. Harris, N. R. Goodwin (Eds.). Twenty-first century macroeconomics: responding to the climate challenge. Edward Elgar Publishing, 138-168.

Oliveira, C.; Antunes, C. H. 2009. An interactive method of tackling uncertainty in interval multiple objective linear programming, Journal of Mathematical Sciences 161(6): 854-866.

http://dx.doi.org/10.1007/s10958-009-9606-9

Oliveira, C.; Antunes, C. H. 2011. A multi-objective multi-sectoral economy-energy-environment model: application to Portugal, Energy 36(5): 2856-2866.

http://dx.doi.org/10.1016/j.energy.2011.02.028

Oliveira, C.; Antunes, C. H. 2012. Interactions of economic growth, energy consumption and the environment in the context of the crisis - a study with uncertain data, Energy 48(1): 415-422. http://dx.doi.org/10.1016/j.energy.2012.04.009

Oliveira, C.; Coelho, D. H.; Silva, P. 2014. A prospective analysis of the employment impacts of energy efficiency retrofit investment in Portugal by 2020, International Journal of Sustainable Energy Planning and Management 2: 81-92.

Oliveira, C.; Coelho, D. H.; Silva, P.; Antunes, C. H. 2013. How many jobs can the RES-E sectors generate in the Portuguese context?, Renewable and Sustainable Energy Reviews 21: 444-455. http://dx.doi.org/10.1016/j.rser.2013.01.011

Rysanek, A. M.; Choudhary, R. 2013. Optimum building energy retrofits under technical and economic uncertainty, Energy and Buildings 57: 324-337. http://dx.doi.org/10.1016/j.enbuild.2012.10.027

Scott, M.; Roop, J.; Schultz, R.; Anderson, D.; Cort, K. 2008. The impact of DOE building technology energy efficiency programs on U.S. employment, income, and investment, Energy Economics 30(5): 2283-2301. http://dx.doi.org/10.1016/j.eneco.2007.09.001

Srdić, A.; Šelih, J. 2011. Integrated quality and sustainability assessment in construction: a conceptual model, Technological and Economic Development of Economy 17(4): 611-626. http://dx.doi.org/10.3846/20294913.2011.603177

Tuominen, P.; Forsström, J.; Honkatukia, J. 2013. Economic effects of energy efficiency improvements in the Finnish building stock, Energy Policy 52: 181-189. http://dx.doi.org/10.1016/j.enpol.2012.10.012

Ürge-Vorsatz, D.; Harvey, D.; Mirasgedis, S.; Levine, M. 2007. Mitigating $\mathrm{CO}_{2}$ emissions from energy use in the world's buildings, Building Research \& Information 35(4): 379-398.

http://dx.doi.org/10.1080/09613210701325883

Carla OLIVEIRA HENRIQUES holds a PhD in Electrical and Computers Engineering (Systems Optimization), a Master degree in Information Management (Management Science) and a BSc in Economics from the University of Coimbra. She is a Professor at ISCAC Business School, Polytechnic Institute of Coimbra. Her research interests, conducted at INESCC, are in the areas of economy - energy environment modelling, input-output analysis, multi-objective linear programming (MOLP) and MOLP uncertainty handling techniques.

Dulce Helena COELHO holds a PhD in the area of Energy Systems and a Master's degree in Electrical Engineering from the University of Coimbra. She is a Professor at the College of Engineering, Polytechnic Institute of Coimbra. Her research interests, conducted at INESCC, are in the areas of urban energy planning, energy efficiency and sustainable development.

Carlos Henggeler ANTUNES received the PhD degree in Electrical Engineering (optimization and systems theory) from the University of Coimbra, Coimbra, Portugal, in 1992. He is a full professor with the Department of Electrical and Computer Engineering, University of Coimbra, and Director of R\&D Unit INESC Coimbra, Portugal. His research areas include multiple objective optimization and energy planning. 